\title{
The influence of human resource competency and entrepreneurial characteristics on the performance of small and medium industries
}

\author{
Rohman Willian; Husni Hasbullah; Fitri Widiastuti; Dahmiri* \\ Faculty of Economics and Business, Universitas Jambi, Indonesia \\ *Towhom correspondence should be addressed.Email: dahmiri@ unja.ac.id
}

\begin{tabular}{|l|l|l|l|l|}
\hline DOI: & Received: & Revised: & Accepted: & Published: \\
10.22437/ppd.v9i2.10603 & 28.09 .2020 & 22.04 .2021 & 14.06 .2021 & 30.06 .2021 \\
\hline
\end{tabular}

\begin{abstract}
The purpose of this study was to describe and analyze the influence of human resources competencies and entrepreneurial characteristics on the performance of the smallmedium-sized food industry with the intervening variable of competitive advantage. This research is verification in nature, basically wants to test the truth of a hypothesis which is carried out through data collection in the field. The unit of analysis in this research is the food SMIs (Small and Medium Industries) actors in Jambi Province. The data were obtained through distributing questionnaires to 378 SMIs food entrepreneurs. The data analysis used was quantitative analysis using Structural Equation Modelling (SEM). The analysis results concluded that the respondents' responses to the variables of human resources competence, entrepreneurial characteristics, competitive advantage, and SMIs performance obtained the average number included in the good scale range. The variables of human resources competency, entrepreneurial characteristics, competitive advantage significantly influence the performance of food SMIs in Jambi Province, either partially or simultaneously. Human resources competency and entrepreneurial characteristics variables have a significant indirect effect on SMIs performance through the intervening variable of competitive advantage. The entrepreneurial characteristics variable is the dominant variable affecting the SMIs performance. The research model by adding the competitive advantage variable as an intervening variable resulted in a better effect on the SMIs performance.
\end{abstract}

Keywords: Competency, Competitive advantage, Entrepreneurial characteristics

JEL Classification: L25, L26, M21

\section{INTRODUCTION}

Influence of human resources competency and the characteristics of entrepreneurship towards the performance of small and medium industries. Small and Medium Industry or SMI plays a very important role at the local and national levels, as evidenced by its considerable contribution to regional and state revenues and very large labor absorption. In order to become an advanced SMI, it must be supported by many aspects, both internal and external. Internal factors that greatly influence the success of SMIs include the competence of qualified human resources, entrepreneurial characteristics, and competitive advantage. Human resources competence is the main asset to make SMIs more professional and superior. The quality of human resources is very important, especially to the competence of human resources in three aspects, 
namely the knowledge aspect, the skill aspect, and the ability aspect (Ardiana et al., 2010).

Entrepreneurial characteristics are a very important factor in managing a business. Entrepreneurial characteristics are a picture of a person's uniqueness, individually or psychologically, including the dimensions of attitude values and dimensions of needs (Indris \& Primiana, 2015).

Competitive advantage can significantly impact the acquisition of profitability and improve business performance (Hitt et al., 2011). Competitive advantage is an advantage that a business unit has over its competitors, which can be achieved by offering consumers more value than competitors, either by giving a lower price or offering more benefits even at a higher price (Kotler et al., 2018).

The development of SMIs in Jambi Province in terms of quantity is quite good, but the phenomenon that occurs frequently is the slow performance of businesses. Initial interviews obtained information that the causes of poor SMIs performance include factors such as human resources competency, entrepreneurial characteristics, and competitive advantage. The importance of this research is to produce a model that can describe how the influence of human resources competencies, entrepreneurial characteristics, and competitive advantage can affect business performance. In the end, this research will produce a SMIs development model and provide recommendations to various parties about what can be done so that SMIs can improve their performance.

\section{LITERATURE REVIEW}

The performance of MSMEs must be accompanied by business development. However, MSMEs development must be accompanied by human resources development in various aspects. Human resources competencies that are very much needed by the business unit include aspects of knowledge, aspects of skills, and aspects of ability (Ardiana et al., 2010). Competency refers to an individual's knowledge, skills, abilities, or personality characteristics that directly influence job performance, meaning that competency has aspects such as knowledge, skills, abilities, and personality characteristics that greatly affect business performance (Yong \& Mohd-Yusoff, 2016). There are 3 (three) characteristics that makeup competency, according to Moeheriono (2012), namely: knowledge, skills, and ability.

Chamduang et al. (2014) explained that entrepreneurial characteristics must support successful SMEs; therefore, entrepreneurial characteristics are very important. One of the importance of entrepreneurial characteristics in determining success or failure (Indris \& Primiana, 2015). Suryana \& Bayu (2012) suggest that entrepreneurial characteristics include: 1) Having high discipline, 2) Being sharp in determining business goals, 3) Having a high sense of intuition, 4) Having a good attitude of courtesy and good manners, 5) Always wanting to learn about various things for the sake of progress, 6) Making a mistake as a lesson, 7) High desire in looking for new opportunities and opportunities, 8) Having the will, ambition, and always think positively, and 9) Like to challenges and risks based on the maturity of calculations and plans.

The company's competitive advantage can be seen from the company's ability to understand and anticipate changes in market structure, and the company can choose an effective marketing strategy to become a winner in the market (Suryana \& Bayu, 2012). According to Istanto (2010), the elements that form competitive advantage in business include the company's potential, company position, and business performance. The indicators that can be used to measure competitive advantage are the uniqueness of the product, the quality of the product offered, and the competitive price. 
The level of achievement of the results of carrying out tasks is called performance (Haider et al., 2018). Business performance is an achievement from various roles participating in a community or organization (Ferdinand, 2014). Measuring the performance of SMEs can use several indicators, namely: 1) Increasing profit growth; 2) Increasing customer growth; 3) Sales growth that is growing rapidly; 4) Asset growth, both fixed and non-fixed assets, is increasing.

\section{METHODS}

\section{Research design}

The data collection tool was a closed questionnaire and was carried out by survey. In survey research, sampling was taken from one population, and the data collection tool used a questionnaire (Arikunto, 2016). The method used was a quantitative analysis, in which statistical tests and research hypotheses were tested.

The population was food SMI entrepreneurs in Jambi Province, as many as 6,894 SMIs (Perindagkop, 2018). The sample could also be defined as the number of characteristics of a subject representative of a population for further research (Quinlan et al., 2019). The research sample was determined by using the Slovin formula (Sevilla et al. 2007), amounting to 378 samples with proportional selection.

The questionnaire used was a structured questionnaire and was closed, with the assessment scores were: Strongly disagree $($ STS $)=1$, Disagree $(T S)=2$, Simply agree $(C S)=3$, Agree $(S)=4$, and Strongly agree $(S S)=5$. The scale ranges were 1.00 to 1.80 , categorized as Strongly disagree, 1.81 to 2.60 in the disagree category, 2.61 to 3.40 in the simply agree category, 3.41 to 4.20 in the agree 4.21 to 5.00 in the Strongly agree category. The research instrument tests conducted were validity test, reliability test, and normality test.

Table 1. Operationalization of research variables

\begin{tabular}{|c|c|c|}
\hline Variables & Definition & Indicator \\
\hline $\begin{array}{l}\text { Human resources } \\
\text { competence } \\
(\mathrm{KSDM})\end{array}$ & $\begin{array}{l}\text { authority to determine; the ability to master } \\
\text { grammar both abstractly and inwardly (KBBI, } \\
\text { 2015) }\end{array}$ & $\begin{array}{ll}\text { - } & \text { knowledge } \\
\text { - } & \text { skill } \\
\text { - } & \text { Ability } \\
\end{array}$ \\
\hline $\begin{array}{l}\text { Entrepreneurial } \\
\text { characteristics } \\
\text { (KKWU) }\end{array}$ & $\begin{array}{l}\text { Entrepreneurial characteristics generally } \\
\text { describe a person's personal or psychological } \\
\text { uniqueness, consisting of attitude and need } \\
\text { values. Entrepreneurial characteristics } \\
\text { determine the success of a business (Sari, } \\
\text { 2016) }\end{array}$ & $\begin{array}{ll}\text { - } & \text { Having high discipline } \\
\text { - } & \text { Watch out for goals } \\
\text { - } & \text { Keen intuition } \\
\text { - } & \text { Polite } \\
\text { - } & \text { Wanting to learn } \\
\text { - } & \text { Having ambition } \\
\text { - } & \text { Always looking for new } \\
& \text { opportunities } \\
\text { - } & \text { Positive thinking } \\
\text { - } & \text { Happy to take risks }\end{array}$ \\
\hline $\begin{array}{l}\text { Competitive } \\
\text { advantage (KBRS) }\end{array}$ & $\begin{array}{l}\text { The ability of a company to obtain economic } \\
\text { benefits above profits that competitors can } \\
\text { achieve in the market in the same industry } \\
\text { (Porter, 1998) }\end{array}$ & $\begin{array}{l}\text { - } \text { Product uniqueness } \\
\text { - } \text { Product quality } \\
\text { - } \text { Competitive price }\end{array}$ \\
\hline $\begin{array}{l}\text { Small and medium } \\
\text { industry } \\
\text { performance } \\
\text { (KIKM) }\end{array}$ & $\begin{array}{l}\text { Business performance is an achievement that } \\
\text { results from the impact of the various roles } \\
\text { that function within an organization } \\
\text { (Ferdinand, 2004) }\end{array}$ & $\begin{array}{ll}\text { - } & \text { Profit growth } \\
\text { - } & \text { Customer growth } \\
\text { - } & \text { Sales growth } \\
\text { - } & \text { Growth in the number of } \\
\text { assets }\end{array}$ \\
\hline
\end{tabular}

\section{Data analysis}

The data analysis used was quantitative analysis using Equation Model Structure (SEM) as the analysis tool. Research modeling using the SEM model provides the 
opportunity to answer research questions, both regressive and dynamic, in 7 steps (Ferdinand, 2014).

\section{RESULTS AND DISCUSSION}

\section{Respondent characteristics}

The analysis results showed that most respondents were women, as many as 210 people or $55.6 \%$. The age of respondents with the highest number was respondents aged $36-45$ years, amounting to 127 people or $33.6 \%$ of the total respondents. The monthly turnover shows that the highest amount was between IDR 10,000,001 - 20,000,000, or as much as $31.7 \%$.

\section{Hypothesis testing and data analysis}

To test a complete hypothesis, it is necessary to draw the full Structural Equation Modelling, which can be seen in Figure 1:

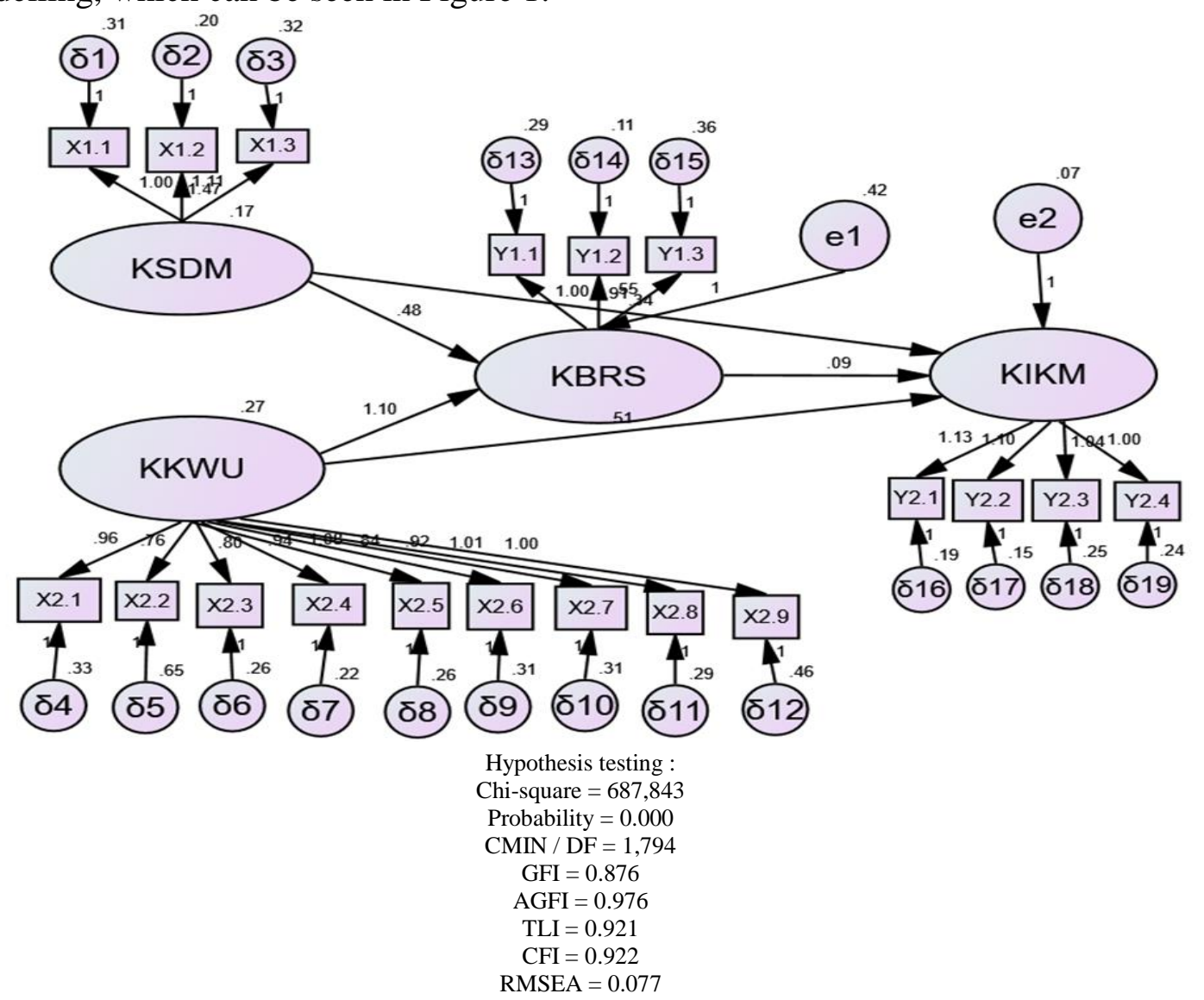

Figure 1. Full Structural Equation Modelling

\section{Goodness of fit test}

The model suitability test shows that the goodness of fit for RMSEA shows 0.077 $<0.08$, GFI $0.876<0.90$, AGFI gets a figure of $0.976>0.90$, CMIN/DF is $1.794<2.00$, TLI is $0.921<0.90$, and CFI is 0.922>0.90. All the assumptions of the goodness of fit are fulfilled according to the conditions. According to Arbuckle \& Wothke (2000), the best criteria used to indicate the model's goodness are CMIN/DF values, which are less than 2, and RMSEA below 0.08. This means that almost all the assumptions of the goodness of fit are fulfilled as what has been required, even though the GFI is in the moderate category. 
All the goodness of the index is generally in accordance with the proposed data and model. From the evaluation of the proposed model, all the criteria used show good results, meaning that the model fits the data and meets the required size, meaning that this model can be analyzed.

Table 2. Summary of research hypothesis testing results

\begin{tabular}{|c|c|c|c|c|}
\hline Hypothesis & $\mathrm{CR} / \mathrm{F}$ value & $\begin{array}{l}\text { T value } \\
(P<0,05)\end{array}$ & $\begin{array}{l}\text { Hypothesis } \\
\text { verification }\end{array}$ & Conclusion \\
\hline \multicolumn{5}{|l|}{ Hypothesis 1} \\
\hline $\begin{array}{l}\text { HR competencies have a } \\
\text { significant effect on competitive } \\
\text { advantage }\end{array}$ & 2,278 & 0,021 & $\begin{array}{c}\mathrm{H} 1 \\
\text { Accepted }\end{array}$ & $\begin{array}{l}\text { HR competencies } \\
\text { significantly influence } \\
\text { competitive advantage }\end{array}$ \\
\hline \multicolumn{5}{|l|}{ Hypothesis 2} \\
\hline $\begin{array}{l}\text { Entrepreneurial characteristics } \\
\text { have a significant effect on } \\
\text { competitive advantage }\end{array}$ & 2,786 & 0,003 & $\begin{array}{c}\text { H1 } \\
\text { Accepted }\end{array}$ & $\begin{array}{l}\text { Entrepreneurial } \\
\text { characteristics affect } \\
\text { competitive advantage }\end{array}$ \\
\hline \multicolumn{5}{|l|}{\begin{tabular}{|c|} 
Hypothesis 3 \\
\end{tabular}} \\
\hline $\begin{array}{l}\text { HR competencies have a } \\
\text { significant effect on SMI } \\
\text { performance }\end{array}$ & 2,327 & 0.010 & $\begin{array}{c}\text { H1 } \\
\text { Accepted }\end{array}$ & $\begin{array}{l}\text { HR competencies have a } \\
\text { significant effect on SMI } \\
\text { performance }\end{array}$ \\
\hline \multicolumn{5}{|l|}{ 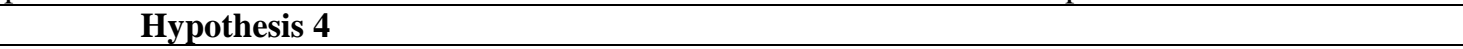 } \\
\hline $\begin{array}{l}\text { Entrepreneurial characteristics } \\
\text { have a significant effect on SMI } \\
\text { performance }\end{array}$ & 2,265 & 0,001 & $\begin{array}{c}\text { H1 } \\
\text { Accepted }\end{array}$ & $\begin{array}{l}\text { Entrepreneurial characteris- } \\
\text { tics have a significant effect } \\
\text { on SMI performance }\end{array}$ \\
\hline \multicolumn{5}{|l|}{$\begin{array}{c}\text { Hypothesis } 5 \\
\end{array}$} \\
\hline $\begin{array}{l}\text { HR competencies and } \\
\text { entrepreneurial characteristics } \\
\text { have a significant effect on } \\
\text { competitive advantage, partially } \\
\text { and simultaneously }\end{array}$ & $\begin{array}{c}\text { Partial : } \\
2,269 \\
2,777 \\
\text { Simultaneous } \\
130.641 \\
\end{array}$ & $\begin{array}{l}0,012 \\
0,004 \\
0,000\end{array}$ & $\begin{array}{c}\mathrm{H} 1 \\
\text { Accepted }\end{array}$ & $\begin{array}{l}\text { HR competencies and } \\
\text { entrepreneurial } \\
\text { characteristics influence } \\
\text { competitive advantage, } \\
\text { partially and simultaneously }\end{array}$ \\
\hline \multicolumn{5}{|l|}{ Hypothesis 6} \\
\hline $\begin{array}{l}\text { HR competencies and } \\
\text { entrepreneurial characteristics } \\
\text { have a significant effect on the } \\
\text { performance of SMIs, either } \\
\text { partially or simultaneously }\end{array}$ & $\begin{array}{c}\text { Partial } \\
2,327 \\
2,265 \\
\text { Simultaneous } \\
142.138\end{array}$ & $\begin{array}{l}0,010 \\
0,001 \\
0,000\end{array}$ & $\begin{array}{c}\mathrm{H} 1 \\
\text { Accepted }\end{array}$ & $\begin{array}{l}\text { HR competencies and } \\
\text { entrepreneurial } \\
\text { characteristics have a } \\
\text { significant effect on the } \\
\text { performance of SMIs, either } \\
\text { partially or simultaneously }\end{array}$ \\
\hline \multicolumn{5}{|l|}{ Hypothesis 7} \\
\hline $\begin{array}{l}\text { Competitive advantage has a } \\
\text { significant effect on SMI } \\
\text { performance }\end{array}$ & 2,055 & 0,028 & $\begin{array}{c}\text { H1 } \\
\text { Accepted }\end{array}$ & $\begin{array}{l}\text { Competitive advantage has } \\
\text { a significant effect on SMI } \\
\text { performance }\end{array}$ \\
\hline \multicolumn{5}{|l|}{ Hypothesis 8} \\
\hline $\begin{array}{l}\text { HR competency, entrepreneurial } \\
\text { characteristics, and competitive } \\
\text { advantage have a significant } \\
\text { effect on SMI performance, } \\
\text { partially and simultaneously }\end{array}$ & $\begin{array}{c}\text { Partial } \\
2,327 \\
2,265 \\
2,055 \\
\text { Simultaneous } \\
125.313\end{array}$ & $\begin{array}{l}0,010 \\
0,001 \\
0,028 \\
0,000\end{array}$ & $\begin{array}{c}\text { H1 } \\
\text { Accepted }\end{array}$ & $\begin{array}{l}\text { HR competency, entrepre- } \\
\text { neurial characteristics, and } \\
\text { competitive advantage } \\
\text { significantly influence the } \\
\text { performance of SMIs, both } \\
\text { partially and simultaneously }\end{array}$ \\
\hline
\end{tabular}

Based on Figure 1, for indirect testing, the full Structural Equation Modelling can be seen in Table 3.

Table 3. Hypothesis testing results of indirect effect

\begin{tabular}{lccc}
\hline Independent Variables & Dependent Variables & Intervening Variables & Path Coefficient \\
\hline HR Competency (X1) & SMIs performance $(\mathrm{Y} 2)$ & Competitive Advantage $(\mathrm{Y} 1)$ & $(0.252) \mathrm{X}(0.587)=0.148$ \\
Entrepreneurial & SMIs performance $(\mathrm{Y} 2)$ & Competitive Advantage $(\mathrm{Y} 1)$ & $(0.446) \mathrm{X}(0.587)=0.262$ \\
Characteristics (X2) & & & \\
\hline
\end{tabular}


Table 3 illustrates the results of the path coefficient analysis of the indirect effect between human resources competency variable (X1) on SMIs performance (Y2) through competitive advantage (Y1), obtained through the product of the direct influence between human resources competency (X1) on SMIs performance (Y2). The path coefficient is $0.252 \mathrm{X} 0.587$, so the indirect effect coefficient is 0.148 . This means that human resources competency $(\mathrm{X} 1)$ has an indirect effect on the performance of SMIs (Y1) through a competitive advantage of $14.8 \%$.

Meanwhile, from the results of the path coefficient analysis, the indirect effect between the entrepreneurial characteristics variable (X2) on the SMIs performance (Y2) is obtained through the product of the direct influence between entrepreneurial characteristics on SMIs performance (Y2), the coefficient value is $0.446 \mathrm{X} 0.587$. Therefore, the coefficient of indirect influence is obtained of 0.262. This means that entrepreneurial characteristics indirectly affect SMIs performance (Y2) through a competitive advantage of $26.2 \%$.

The results of hypothesis 1 testing explain that human resources competency affects competitive advantage in food SMIs in Jambi Province, so that what food SMIs do with regard to the dimensions of human resources competency will increase the competitive advantage of food SMIs. The food SMIs can do this by increasing knowledge, skills, and abilities.

The results of hypothesis testing 2 show that the entrepreneurial characteristics of food SMIs in Jambi Province affect competitive advantage. The food SMIs demonstrate this by having high discipline, being aware of goals, sharp intuition, being polite, willing to learn, having ambition, looking for new opportunities, positive thinking, and being happy to face risks.

The results of testing Hypothesis 3 explain that the competence of human resources possessed by food SMIs in Jambi Province affects the performance of SMIs. The performance of an MSME business unit is strongly influenced by the ability and quality of its human resources. The performance of MSMEs must be accompanied by business development; however, MSME development must be accompanied by human resources development in various aspects. Human resources competence is very much needed by business units (Ardiana et al., 2010).

The results of testing Hypothesis 4 explain that the entrepreneurial characteristics of food SMIs in Jambi Province will improve the performance of SMIs. Entrepreneurial characteristics are psychological characteristics that describe the characteristics of an entrepreneur, namely: 1) Having a high self-confidence, 2) Always having an orientation towards tasks and results, 3) Like risks and like challenges, 4) Having a good leadership spirit, 5) Always creative and original, 6) Having a far future orientation (Mubaraki \& Busler, 2013).

The analysis results show that human resources competence partially affects competitive advantage, which is indicated by the CR value of $2.269>1.96$, and the Pvalue of 0.012 is less than 0.05 ( $p<0.05)$. Likewise, the entrepreneurial characteristics variable partially affects competitive advantage, which is indicated by the CR value of 2.777> 1.96, and the P-value of 0.004 is less than $0.05(\mathrm{p}<0.05)$. The two variables are causal and influence each other. Therefore, the hypothesis that human resources competence and entrepreneurial characteristics affect the competitive advantage of SMIs can be accepted.

The results of data analysis show that human resources competency partially affects the performance of SMIs, which is indicated by the CR value of 2.327 , and the P-value of 0.010 is less than 0.05 ( $\mathrm{p}<0.05)$. The two variables are causal and influence each other. Then the hypothesis which states that human resources competency affects the performance of SMIs is accepted. Likewise, entrepreneurial characteristics partially 
affect the performance of SMIs, the CR value is 2.265, and the P-value is 0.001 , which is less than 0.05 ( $\mathrm{p}<0.05)$. This means that entrepreneurial characteristics affect SMIs performance. This shows that the better the entrepreneurial characteristics, the better the performance of food SMIs in Jambi Province.

The results of testing Hypothesis 7 explain that the competitive advantage possessed by small and medium-sized food industries in Jambi Province will improve the performance of SMIs. The level of achievement of the results of carrying out tasks is called performance (Haider et al., 2018). Business performance is an achievement from an impact of various roles participating in a community or organization (Ferdinand, 2014). The findings show that the performance of food SMIs in Jambi Province will depend on how good the competence of human resources, entrepreneurial characteristics, and competitive advantage. The results of this study also indicate that the food SMIs actors in Jambi Province are quite realistic in providing an assessment of their SMIs. This fact also shows that SMIs customers must improve the three existing variables, namely human resources competency, entrepreneurial characteristics, and competitive advantage.

This research is in line with previous research. The factors that cause food SMIs to be slow in their development are low performance, poor quality of human resources, weaknesses of entrepreneurial characteristics, and weaknesses of competitive advantage. To improve the performance of food SMIs to develop, the support of all parties is needed so that the right model is found in improving the quality of human resources, entrepreneurial characteristics, and competitive advantage (Bruch \& Hiemenz, 2019).

\section{CONCLUSION AND RECOMMENDATION}

\section{Conclusions}

The partial analysis of human resources competency, entrepreneurial characteristics, and competitive advantage significantly influences the performance of food SMIs in Jambi Province. Meanwhile, it simultaneously shows that human resources competency, entrepreneurial characteristics, and competitive advantage affect the performance of SMIs.

The path coefficient analysis of the indirect effect between the human resources competency variables on the performance of SMIs has an indirect effect on the performance of SMIs through competitive advantage. Meanwhile, from the results of the path coefficient analysis, the indirect effect between the entrepreneurial characteristics variable on the SMIs performance has an indirect effect on the SMIs performance through competitive advantage.

The analysis results found that the entrepreneurial characteristics variable was the more dominant variable affecting the performance of food SMIs in Jambi Province. The research model by adding the competitive advantage variable as the intervening variable resulted in the finding of a better effect on the performance of SMIs.

\section{Recommendations}

One of the concepts that can be applied and suggested is the SME strategic policy, which is performance-oriented. The government is expected to make policies that favor the interests of SMIs., fostering and supervising the SMIs in their working area. In making the rules, it is hoped that the government will side with SMIs. It will create an increase in the performance of the SMIs.

This study chooses the object of the food SMIs. The next researchers will conduct research on other SMIs such as crafts and fashion. They can also use other variables as exogenous or independent variables and the variables included in the research. 
Therefore, it can be seen whether there are similarities or differences between the two groups of SMIs and the similarities and differences with the research results.

\section{REFERENCES}

Ardiana, I.D.K.R. \& Brahmayanti, I.A. \& Subaedi, S. (2010). Kompetensi SDM UKM dan Pengaruhnya Terhadap Kinerja UKM di Surabaya. Jurnal Manajemen dan Kewirausahaan Universitas, 12(1), 42 - 55

Arikunto, S. (2016). Prosedur Penelitian Suatu Pendekatan Praktik. Jakarta: Rineka Cipta.

Bruch, M., \& Hiemenz, U. (2019). Small-and medium-scale industries in the ASEAN countries: agents or victims of economic development?. New York: Routledge.

Chamduang, S., Daowieng, P., \& Jorajit, S. (2014). Effect of Entrepreneurial Characteristics on the Business. Proceeding Sufficiency Economy and Community Enterprise-001, $4^{\text {th }}$ International Conference on Humanities and Social Sciences, April 21 ${ }^{\text {st }}, 2012$, Faculty of Liberal Arts, Prince of Songkla University

Haider, S.H., Officer, C.S., Asad, M., \& Fatima, M. (2018). Microfinance and Performance of Micro and Small Enterprises; Does Training have an Impact. International Journal of Small Business and Entrepreneurship Research, 6(4), 40 - 49.

Hitt, M.A., Ireland, R.D., Sirmon, D.G., \& Trahms, C.A. (2011). Strategic entrepreneurship: creating value for individuals, organizations, and society. Academy of management perspectives, 25(2), 57-75..

Indris, S. \& Primiana, I. (2015). Internal and external environment analysis on the performance of small and medium industries (SMEs) in Indonesia. International journal of scientific \& technology research, 4(4), 188-196.

Istanto, Y. (2010). Pengaruh Strategi Keunggulan Bersaing dan Positioning Terhadap Kinerja (Survey Pada Koperasi Serba Usaha di Kabupaten Sleman Yogyakarta). Bulletin Ekonomi, 8(2), 124-135.

Kotler, P., Keller, K.L., Ang, S.H., Tan, C.T., \& Leong, S.M. (2018). Marketing management: an Asian perspective. Pearson.

Moeheriono (2012). Pengukuran Kinerja (Berbasis Kompetensi). Jakarta: PT. Raja Grafindo Persada.

Mubaraki, H.M. \& Busler, M. (2013). Business incubation as an economic development strategy: A literature review. International Journal of Management, 30(1), 362373

Quinlan, C., Babin, B., Carr, J. \& Griffin, M. (2019). Business research methods. South Western Cengage.

Sevilla, C. (2013). Pengantar Metode Penelitian. Jakarta: Universitas Indonesia

Suryana, Y. \& Bayu, K. (2012). Kewirausahaan: Pendekatan Karakteristik Wirausahawan Sukses. Jakarta: Kencana.

Yong, J. Y., \& Mohd-Yusoff, Y. (2016). Studying the influence of strategic human resource competencies on the adoption of green human resource management practices. Industrial and Commercial Training, 48(8), 416-422

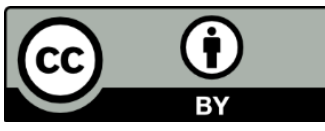

(C) 2021 by the authors. Licensee JPPD, Indonesia. This article is an open-access article distributed under the terms and conditions of the Creative Commons Attribution (CC BY) license (http://creativecommons.org/licenses/by/4.0/). 